\title{
Audit Quality of Second-Tier Auditors: Are All Created Equally?
}

\author{
R. Mithu Dey and Lucy S. Lim
}

R. Mithu Dey is an Associate Professor and Lucy S. Lim is an Assistant Professor at Howard University. Correspondence information: R. Mithu Dey, Associate Professor of Accounting, Howard University, 2600 Sixth Street, NW, Washington, DC 20059, Phone 202-806-1565, Fax 202-986-4160, email mithu@howard.edu or mithu@rit.edu

This research was supported in part by a grant from the RIT Sauder's College of Business.

\begin{abstract}
Policy makers and regulators are interested in increasing auditor choice. A common problem faced by large firms is that one auditor is for external audit, a second for internal audit, a third for tax, a fourth for consulting (Cox, 2005; GAO, 2008, p. 22). A possible option for alleviating this auditor choice problem is to have the second-tier auditors as an acceptable alternative to the Big 4. The second-tier auditors include BDO, Grant Thorton, Crowe, and McGladrey. According to a 2003 U.S. General Accounting Office (GAO, 2003) survey of large public firms, the major consideration in auditor choice is audit quality. We examine audit quality
\end{abstract}


of each of the second-tier auditors to determine if auditor choice is being increased while maintaining audit quality. We use two common measures of audit quality, earnings response coefficient and abnormal accrual, during the 2000 to 2010 period. We find no significant statistical difference in audit quality among the second-tier auditor especially in the period after Sarbanes-Oxley Act. The results should be comforting to policy makers and regulators, who are interested in increasing auditor choice.

Keywords: audit quality, second-tier auditors, audit competition

Data Availability: Data used in this study are available from public sources.

DOI: http://dx.doi.org/10.15239/j.brcacadjb.2014.04.01.ja01

\section{INTRODUCTION}

Policy makers and regulators are interested in increasing auditor choice. A common problem faced by large firms is that one auditor is for external audit, a second for internal audit, a third for tax, a fourth for consulting (Cox, 2005; GAO, 2008, p. 22). The options are constrained when considering auditor change, a problem that is further aggravated when a firm does not want to share the auditor of a competitor due to privacy needs (Dey, 2010; Kwon, 1996). A possible option for alleviating this auditor choice problem is to have the second-tier auditors as an acceptable alternative to the Big 4 . The second-tier auditors include BDO Seidman (BDO), Grant Thorton (GT), Crowe (CR) and McGladrey (MC). According to a 2003 U.S. General Accounting Office survey (GAO, 2003) of large public firms, the major consideration in auditor choice is audit quality. We examine audit quality of each of the second-tier auditors to determine if auditor choice is being increased while maintaining audit quality.

Since the demise of Andersen, policy makers and regulators have shown concern with limited auditor choice and have encouraged an 
increase. In the Sarbanes-Oxley Act of 2002 (hereafter referred to as SOX), policy makers included in Section 701 a study required by GAO "to identify ways to increase competition and number of firms capable of providing audit services to large national and multinational business organizations...and of the problems, if any, faced by business organizations that have resulted from limited competition among public accounting firms, including lack of choice." The GAO (2003) study finds that a major impediment for second-tier auditors is credibility with financial markets, bankers and lenders. To establish such credibility, regulators encouraged firms to consider second-tier auditors. For instance, such encouragement was made by SEC Chairman Cox (2005) in front of members at an AICPA National Conference. Also, Kayla Gillian, a PCAOB member, "suggest(s) that the Audit Committees should also consider the so-called 'second tier' of audit firms." This and other encouragement may have been effective since the GAO (2008) study finds second-tier auditors increasing market share for clients with revenues below $\$ 1$ billion, generally below Fortune 1000 firms. Thus, for certain size clients, it appears that auditor choice is improving.

Audit quality of second-tier clients has also improved since SOX. Audit quality is inherently unobservable; thus, several proxies for audit quality are commonly used. Various studies of second-tier audit quality reflect improvements in measures such as financial reporting credibility (Cassell, Giroux, Myers, and Omer, 2011), financial reporting quality (Boone, Khurana, and Raman, 2010), earnings conservatism (Jenkins and Velury, 2011), and more positive stock market reaction (Chang, Cheng, and Reichelt, 2010). In general, these studies portray a consistent story of second-tier audit quality improving post-SOX.

The motivation for our paper stems from several sources. First, although prior studies have consistently found an improvement in audit quality of second-tier clients in the post-SOX period, we find no evidence that the quality of each of the second-tier auditors is similar. If any of the second-tier auditor quality dominates the others then the difference 
among the second-tier auditors will not show up in those studies. By examining the different audit quality among the second-tier, we will be able to determine if audit quality differs among the second-tier auditors. Second, we note that studies of second-tier audit quality differ on which firms are included in the definition of second-tier, which may raise a question whether audit quality of the four auditors differ. Although each of the second-tier auditors differ in some respects, such as size, geographic region, and industry (Dey and Robin, 2011), this leads to different classification such as GT and BDO versus MC and CR; however, we do not know if they differ in terms of audit quality. Third, Chang et. al. (2010) finds the market rewards auditor switching from Big 4 to BDO and GT from 2002 to 2006, and Big 4 to CR and MC since 2004. They suggest that "investors have become more receptive to smaller accounting firms since these firms, like Big 4, may also be competent in providing high quality audit services to public companies." We specifically test the audit quality of the second-tier auditors. Thus, our research question regarding the differences and/or similarities of audit quality of each individual auditor in the second-tier relative to the group is motivated by the push by regulators to increase auditor choice, prior studies on the changes in audit quality for the second-tier but not its individual firms, and the decision by academics not to use all four second-tier auditors in audit quality studies.

The remainder of our paper is structured as follow. The next section reviews prior literature on auditor choice and second-tier audit quality. The third section explains the hypotheses, and the fourth section examines the methodology. The fifth section reviews the results leading to the final section which concludes the paper. 


\title{
Prior Literature
}

\begin{abstract}
Auditor Choice
Constraints on auditor choice are felt by large firms. After hiring an external auditor, internal auditor, tax accountant, and consultant, a firm may feel it has limited options for switching to a new auditor. For some firms seeking privacy choosing an auditor different from that of their competitor aggravates the auditor choice constraint even more. Some larger firms may feel that a second-tier auditor is not an option due to limited resources to audit a large multinational firm.
\end{abstract}

GAO $(2003 ; 2008)$ studies on audit competition identify the barriers second-tier auditors face and the progress in large client market penetration. Shortly after SOX, GAO (2003, p. 83) surveys revealed that large domestic or multinational public companies see two major impediments to competition for the second-tier: not being a Big 4 firm (74\%) followed by credibility with financial markets and investment bankers $(64 \%)$. Thus, clients would not consider using a non-Big 4 for the following reasons: technical skill/knowledge of industry (63\%), reputation of audit firm (58\%), capacity of audit firm (50\%), geographic presence (38\%), obligation with banks or lenders to use only a Big $4(26 \%)$, and Board of Directors would not allow it (25\%) (GAO, 2003, p. 94). The second-tier auditors faced several barriers that needed to be dealt with including credibility with financial markets, bankers and lenders.

Various agencies worked to lower some of the barriers faced by second-tier auditors. At an AICPA conference in 2005, SEC Chairman Cox questioned the wisdom of "intense concentration in the market for large public company auditing services" when "the Commission staff have found that there are many medium and small accounting firms that provide high quality audit services." Cox also questioned "whether we can rewrite our rules to eliminate barriers to entry for new competitors in the large-company auditing market." Additionally, a study commissioned by GT shows that the share price of a client does not decrease 
after a switch from Big 4 to GT. Slowly, some of the barriers for secondtier auditors to audit large clients are being chipped away. A Wall Street Journal article in 2006 notes that "midtier firms such as Grant Thornton LLP and BDO Seidman LLP point to growing lists of clients with higher market values and a warmer reception to their services than in the past from Wall Street investment banks."

The GAO (2008) study documents the progress of the second-tier from 2002 to 2006, from the beginning of SOX to full implementation of SOX 404. By partitioning client revenue in four categories, the GAO study documents success by the second-tier in the two middle categories (GAO, 2008, p. 19). The client revenue categories and percent increase in each for the second-tier auditors are as follows: client revenue less than $\$ 100$ million (remains at $10 \%$ ), revenue between $\$ 100$ and $\$ 500$ million (increased from $6 \%$ to $16 \%$ ), revenue between $\$ 500$ million to $\$ 1$ billion (increased from $2 \%$ to $6 \%$ ), and revenue in excess of $\$ 1$ billion (increased from $1 \%$ to $2 \%$ ). Dey and Robin (2012) find that the second-tier auditors have been effectively managing / maintaining the risk level of their client portfolio, by accepting larger riskier clients but on the other hand dropping smaller riskier clients since SOX. In general, second-tier auditors and smaller auditors were successful in increasing market share in the lower revenue clients at the expense of the Big 4. Smaller auditors had the greatest success in the first two revenue categories while the second-tier auditors were more successful in the middle two categories. Auditor choice is increasing for some clients but for clients with revenue in excess of $\$ 1$ billion, generally Fortune 1000 companies, auditor choice remains the same.

\section{Second-tier Audit Quality}

When clients choose an auditor, the following factors are taken into account, ranked in order of importance: quality of services $(76 \%)$, industry expertise (51\%), and auditor reputation (43\%) (GAO, 2003, p. 96). Audit quality is important in choosing an auditor and there are numerous studies on audit quality. However, there are only a handful 
of studies concerning the market for second-tier auditors. The major themes in this second-tier auditor literature include the quality of auditing services and the evolution of the client portfolio (Dey and Robin, 2012; Hogan and Martin, 2009). We contribute additional insights concerning the audit quality of the individual firms in the second-tier market.

Audit quality can only be measured indirectly. Although prior studies have used various measures to proxy for audit quality in the second-tier, the findings consistently indicate improved audit quality post-SOX. For instance, Cassell et al. (2011) find that financial reporting credibility of second-tier clients improved to Big 4 level post-SOX/Andersen period, and was no longer at the level of other non-Big 4 firms. Boone et al. (2010) find that financial reporting quality is similar for Big 4 and second-tier audit clients but investors perceive accounting information audit quality to be higher for the Big 4. Jenkins and Velury (2011) find that earnings conservatism is greater in the post-SOX period for Big-N/secondtier relative to all other auditors. Chang et al. (2010) find that clients switching from Big 4 to second-tier auditors experienced a more positive stock market reaction in the post-SOX Section 404. Church and Shefchik (2012) find that PCAOB inspection reports of the Big 4 are generally consistent with those of the second-tier. Cullinan et al. (2012) find that the market does not react more negatively when clients move from a Big 4 to a second-tier auditing firm than when clients move from a Big 4 to another Big 4 firm. Gray and Ratzingler (2010) find that a component of the positive change is attributed to the fact that many new second-tier clients were previously with the Big 4 . In general, the small second-tier audit quality research indicates an improvement in audit quality postSOX.

Chang et al. (2010) and Boone et al. (2010) include only GT and BDO as a second-tier auditor, which may raise a question on regarding differences in audit quality. The Cassell et al. (2011) study includes three firms: GT, BDO and MC. Since there are only a handful of papers on second- 
tier audit quality, this inconsistency in which firms are included in the second-tier also raises questions regarding the audit quality of each individual auditor relative to the other auditors in the second-tier.

\section{HYPOTHESES}

As auditor choice has decreased since the Big 8 mergers and the fall of Andersen, regulators and others are attempting to increase auditor choice by encouraging firms to choose from the second-tier auditors as part of the new Big 8 (Cox, 2005; GAO, 2003; Lavieri, 2005). Even though the Big 4 have public clients in the thousands while the second-tier auditors have public clients in the hundreds, heads of the Big 4 are even beginning to use the Big 8 term (O'Sullivan, 2007). Although secondtier auditors differ in some respects, such as size, geographic region, and industry as noted by Dey and Robin (2011), we do not know if they differ in terms of audit quality. Regulators and Big 4 auditors have referred to the second-tier auditors as being part of the new Big 8; however, is that magic number out of nostalgia or should all four be included? Researchers include two, three, or four firms in the second-tier. This inconsistency raises a question of whether all four belong in the secondtier category because their auditor quality is similar or because regulators want the new Big 8. Historically, auditor quality of a single firm has been examined after failures such as those of Laventhol and Andersen, but we feel it may be prudent to examine the individual audit quality now, before failure (Krishnan and Lim, 2013; Lai and Gul, 2008).

Recent studies have compared second-tier audit quality to that of the Big 4 and non-Big 4 . The results indicate that pre-SOX, the second-tier auditors were of lower quality than the Big 4; after SOX, the audit quality is similar to the Big 4. Additionally, pre-SOX second-tier auditors' audit quality was similar to the remaining non-Big 4, while post-SOX the audit quality is higher than the remaining non-Big 4 . With the change in audit 
quality and the push for increased auditor choice, there is a need to examine the audit quality of each of the second-tier auditors.

Consistent with the literature in this area, we use two common measures of audit quality: earnings response coefficients as a measure of perceived audit quality and abnormal accruals as a measure of actual audit quality.

\title{
Earnings Response Coefficients
}

An auditor certifies the credibility of reported earnings numbers. The higher the audit quality, the more confidence investors will have in the reported earnings which then dictate the changes in security prices (Teoh and Wong 1993). Studies use a measure that can reflect differential earnings management and general error generation, such as the earnings response coefficient (ERC).

High (low) ERCs signify high (low) audit quality. Therefore, if investors evaluate one of the second-tier auditors audit quality as being lower than that of the other three second-tier auditors, then we expect ERCs of one of the second-tier clients to be lower than ERCs of clients of the other second-tier auditors. Our first hypothesis (H1), stated in alternate form, is as follows.

H1: ERCs of one of the second-tier auditor's clients are lower than ERCs of the remaining second-tier auditors.

\begin{abstract}
Abnormal Accruals
The magnitude of abnormal accruals is used as an indication of earnings management (Jones, 1991; Frankel, Johnson and Nelson, 2002). Prior studies (e.g. Boone et al. 2010) argue that the higher the audit quality, the lower the magnitude of abnormal accruals. To investigate whether one of the second-tier auditors allows its clients more or less flexibility in the provision of discretionary accruals than the other three second-
\end{abstract}


tier auditors, we estimate the abnormal accrual. Our second hypothesis (H2), stated in alternate form, is as follows.

H2: Abnormal accruals of one of the second-tier auditor's clients are lower than abnormal accruals of the remaining second-tier auditors.

\section{Methodology}

We conduct tests to compare the audit quality of an individual secondtier auditor to the remaining second-tier auditors from 2000 to 2010 . The first test compares the ERCs of audit clients. The second test compares the abnormal accruals of audit clients. We discuss these tests below.

\section{Earnings response coefficients}

To compare ERCs of the second-tier audit clients, we estimate equation 1 in Appendix 1, where variables are as defined in Exhibit 1. Our ERC model is derived from Kumar and Lim (2013), which includes all the necessary control variables to measure audit quality using earnings quality (ERCs). An ERC model captures market reactions to earnings surprises. Our variables of interest are the coefficients on the interaction between earnings level (E) and the second tier auditors' dummies $\left(\mathrm{a}_{6}, \mathrm{a}_{7}\right.$, and $\mathrm{a}_{8}$ ). A positive (negative) and significant $\mathrm{a}_{6}, \mathrm{a}_{7}$, or $\mathrm{a}_{8}$ indicate higher (lower) ERCs for BDO, MC, or CR clients, respectively, than those for GT clients. GT is chosen arbitrarily as the base in this model.

The dependent variable is size-adjusted returns (SAR), which is a firm's buy-and-hold return adjusted by a size-matched portfolio's buyand-hold return over a period beginning the fourth month of the fiscal year through the third month of the following fiscal year. ERC is represented by the coefficient estimate for earnings level $(E)^{1}$. The higher the quality of earnings, the more the market will react to earnings surprises. Arguably, a high (low) earnings quality reflects a high (low) audit quality. Following prior research (e.g. Ali and Zarowin, 1992; Easton and Harris, 1991), we measure earnings surprises using not only earnings 
changes, but also earnings levels. Earnings level is included in the regression because annual earnings have transitory components and in turn earnings level will increase the explanatory power of earnings surprises.

The model includes the main effect of the control variables (BETA, G, PERSIST, LOSS, TENURE, LnTA) to control for potential direct impact of these control variables to size-adjusted returns. The interactions between the control variables and earnings level will show the impact of the control variables to ERCs.

Collins and Kothari (1989) show that risk (BETA), growth (G), and earnings persistence (PERSIST) affect ERCs. Generally, the higher (lower) the risk results in lower (higher) ERCs. Risk (BETA) is the estimated slope coefficient from a regression of market daily return on a firm daily return over a one-year period starting the fourth month of a fiscal year. Growth is measured as the ratio of market value of equity to book value of equity at the beginning of the fiscal year. It can have a positive or negative effect on ERCs. Persistence (PERSIST) has a positive relationship with ERCs. Following Ali (1994), PERSIST is one when the absolute value of price-deflated earnings changes is below the median and zero otherwise. Loss is expected to have a negative effect on ERCs. Hayn (1995) found that earnings loss has less information content than profit because loss is not expected to continue; therefore, investors respond less to loss than profit. LOSS is one when earnings is less than zero and zero otherwise.

Auditor tenure (TENURE) can have a positive or negative impact on ERCs. Ghosh and Moon (2005) found that as auditor tenure increases, audit quality (measured using ERCs) also increases. However, there is a possibility that as auditor tenure is high, auditor independence might be affected and might result in low audit quality. There are various results related to the effect of firm size to ERCs. Firm size might have a negative relationship (Atiase, 1985; Freeman 1987), no relationship (Collins and Kothari, 1989), or a positive relationship (Chaney and Jeter, 1992) 
with ERCs. We measure firm size as the natural logarithm of total assets (LnTA).

\section{Abnormal Accruals}

The model we use to calculate abnormal accruals is from Dechow, Richardson and Tuna (2003) and include firm performance measure (ROA) to control for its effect on total accrual (Kothari, Leone and Wasley, 2005). The model is run for each two-digit SIC code and year grouping. Abnormal accrual is the residual from the model. The accrual model is estimated using equation 2 and 3 in Appendix 1. Equation 3 in Appendix 1 estimates the expected increase in receivable which should be classified as normal accrual.

Total accrual (TotAcc) is income before extraordinary items minus cash flow from operations. Change in receivable (Ch_Rec) and change in sales (Ch_Sales) are current year number minus previous year number. Coefficient $b_{1}$ in equation 2 (Appendix 1 ) is expected to be positive as expected change in accounts receivable should have a positive relationship to normal accrual. Coefficient for property, plant, and equipment (PPE) is expected to be negative as increase in PPE will increase depreciation expense, which in turn will decrease income. Lag value of total accruals (LagTotAcc) is included in the model to control for serial correlation in accrual. All these variables are deflated by average total assets.

Sales growth (Gr_Sales) is percent sales growth for the following year relative to the current year. Coefficient for $\mathrm{Gr}$ _Sales $\left(\mathrm{b}_{4}\right)$ is expected to be positive. To anticipate increase in sales, a company may increase its inventory, which in this case is not earnings management; thus, such an increase should not be classified as abnormal accrual.

Kothari et al. (2005) show that company performance plays a role in the level of abnormal accrual. Following Rajgopal and Venkatachalam (2011), Return on Assets (ROA) is included in the model as one of the control variables. ROA is measured as income before extraordinary items divided by average total assets. 
In addition to univariate comparisons of abnormal accruals among the second-tier auditors, we also run a multivariate analysis to compare absolute value of abnormal accruals using a model from Lai and Gul (2010) - Equation 4 in Appendix 1.

The dependent variable is the absolute value of abnormal accruals estimated using Equation (2). BDO, MC, and CR are dummy variables that are coded one if the firm is a BDO, MC or CR client, respectively, and zero otherwise. These dummy variables are our variables of interest. A positive (negative) and significant coefficient on BDO, MC, and/or CR indicates that $\mathrm{BDO}$ clients, $\mathrm{MC}$ clients, and/or CR clients, respectively, have greater absolute value of abnormal accruals than GT clients.

The model controls for the absolute value of total accrual deflated by beginning total assets (ABSAC) and change in net income (CHNI) which are both expected to have positive signs. Firms with larger absolute value of total accruals and larger change in net income are expected to have larger absolute value of abnormal accruals. CHNI is a dummy variable. It is coded as one when it is in the top two deciles or zero otherwise. Firms with large ratio of debt to total assets (DA) are expected to have larger absolute value of abnormal accruals as these firms may use abnormal accruals to stay within their debt constraints. Ratio of market to book value of equity (MB) is expected to have a positive sign, as firms with high investment opportunity may need more outside financing and hence are more likely to have a higher absolute value of abnormal accruals. LOSS is coded one when a firm experiences a loss and zero otherwise and is included in the model to control for firm performance. $\log \mathrm{TA}$ is the natural logarithm of total assets and is included in the model to control for potential omitted correlated variables. Cash Flow (CFLOW) is expected to have a negative relation to absolute value of abnormal accruals. 


\section{Sample and Descriptive Statistics}

\section{Sample}

Our analysis covers the period of 2000 to 2010, and we obtained our data from Standard and Poor's Compustat and The Center of Research in Security Price (CRSP). We draw the sample twice, once for the test of differences in ERCs and the second time for the test of differences in abnormal accruals. The sample selection process is in Table 1. Panel A describes the sample selection for the tests of differences in ERCs. We start off with 6,713 observations with the necessary data from Compustat. We eliminate 2,173 observations that have missing CRSP data or have multiple classes of the same security.

We delete 253 potential extreme values. Similar to Collins and Kothari (1989), we define extreme values as those observations with beginning-of-year price below $\$ 1$ and when the magnitude of market-valuescaled earnings changes exceeds $150 \%$. Thus, the sample for the ERC test includes 4,287 observations. We also winsorize several variables to handle potential outliers. Specifically, we winsorize earnings level and lag earnings level at 1.5 and -1.5 , growth at 0 and 30 , size-adjusted return at 5 , and BETA at 3.5 and -1.5 .

Table 1 Panel B explains the sample selection for the tests of differences in abnormal accruals. We start off with 4,447 observations with the necessary data in Compustat for the abnormal accruals analysis, while excluding financial firms and regulated firms. Before running the Dechow et al. (2003) accrual models, we delete 446 extreme outliers at the 1st and 99th percentiles. Additionally, we delete observations when there are fewer than 10 observations in each 2-digit SIC code and year grouping. After we obtain abnormal accruals from the Dechow et al. (2003) model and get all the necessary variables from Compustat to run the multivariate analysis on the differences in abnormal accruals, we delete 90 observations which have values greater than four standard 
deviations from the mean for each continuous variable. We ended up with 2,632 observations.

\section{Descriptive Analysis}

The descriptive statistics and Pearson (Spearman) correlations for the variables included in the tests of differences in ERCs are in Table 2 Panel A and Table 3 Panel A, respectively. The descriptive statistics and Pearson (Spearman) correlations for the variables included in the test of differences in abnormal accruals is in Table 2 Panel B and Table 3 Panel $\mathrm{B}$, respectively.

In Table 4, we conduct univariate comparisons between a specific second-tier auditor versus the remaining three second-tier auditors. We examine both the difference in mean and median for the ERC analysis in Table 4 Panel A and the abnormal accrual analysis in Table 4 Panel B. For the categorical variables, we conduct a test of differences in proportions.

In Table 4 Panel A Sub-Panel I, we compare the variables for the ERC analysis of Grant Thornton clients and other second-tier clients. We find that, compared to other second-tier clients, Grant Thornton clients have higher size-adjusted return (SAR), earnings level (E), and risk (BETA); have lower firm size (LnTA); and experience fewer earnings loss (LOSS).

For BDO (Table 4 Panel A Sub-Panel II), we find that, compared to other second-tier clients, BDO clients have lower earnings level (E), lower lag value of earnings level (LagE), smaller size firms (LnTA), larger risk (BETA), higher growth (G), longer auditor tenure, more losses, and fewer persistence earnings. For McGladrey (Table 4 Panel A Sub-Panel III), we find that MC clients on average have lower risk (BETA), lower growth $(G)$, lower auditor tenure (TENURE), and smaller firm size than other second-tier clients. For CR (Table 4 Panel A Sub-Panel IV), we find that $\mathrm{CR}$ clients on average have lower size-adjusted return, lower risks, lower growth, lower auditor tenure, larger firm size, fewer losses, and more persistent earnings than other second-tier clients. 
In summary, comparing the means across the Sub-Panels for Table 4 Panel A, we find that GT clients have the highest mean of size-adjusted returns. These high returns are supported with the second highest mean of earnings level (E) after MC clients, the second highest mean of risk (BETA) after BDO clients, and the second lowest frequency of loss (LOSS) after CR clients. BDO clients seem to be the riskiest among the secondtier auditor clients. Among the second-tier auditor clients, BDO clients have the second lowest earnings level (E) after CR clients, the highest risk (BETA), the highest growth opportunity $(\mathrm{G})$, the highest frequency of loss (LOSS), and the lowest frequency of persistent earnings. Despite these facts, BDO seems to enjoy the longest relationship (TENURE) with their clients.

Crowe has the smallest number of observations at 352 . CR is the smallest among the second-tier auditors in terms of number of publicly traded clients but appears to have larger clients (mean of natural logarithm of total assets is the highest at 6.5478). Although its clients are larger and have the fewest losses (LOSS) compared with other secondtier clients, but their size-adjusted return (SAR) and growth $(\mathrm{G})$ means are the lowest among the second-tier clients. CR seems to have the shortest relationship (TENURE) with its clients. CR client characteristics appear to be on the extreme among the second-tier clients.

Table 4 Panel B shows the comparisons of mean and median for the variables in the performance-controlled Dechow et al. (2003) accrual model. Sub-Panel I compares GT clients with other second-tier clients. GT clients in general have higher property, plant, and equipment (PPE) and higher return on assets (ROA). In Sub-Panel II, we see that BDO clients have lower total accruals (TotAcc), lower change in sales, lower property, plant, and equipment (PPE), and lower return on assets (ROA). Sub-Panel III shows that MC clients have higher total accruals (TotAcc). Sub-Panel IV shows that CR clients have higher total accruals (TotAcc), higher lag value of total accruals (LagTotAcc), higher return on assets (ROA), and lower sales growth (GrSales). 
If we compare the mean of the variables among the second-tier clients, we find that BDO clients have the lowest mean of total accrual (TotAcc), change in sales, property, plant, and equipment (PPE), and return on assets (ROA). On the other hand, CR clients have the highest mean of total accrual (TotAcc), lowest sales growth (GrSales), and highest return on assets (ROA). It seems that the high ROA is coming from accrual instead of cash income.

Table 4 Panel $\mathrm{C}$ shows the comparisons of mean and median for the variables in the multivariate test of differences in discretionary accruals. Sub-Panel I shows the comparisons of GT clients with other second-tier clients. GT clients have lower ratio of debt to total assets (DA), higher firm size (LogTA), higher cash flow (CFLOW), and fewer losses (LOSS) than other second-tier clients. Sub-Panel II shows BDO clients have lower cash flow (CFLOW), more loss (LOSS) and more firms with large change of income (CHNI). Sub-Panel III shows MC clients have fewer frequency of high change in income (CHNI). Sub-Panel IV shows CR clients have lower absolute value of total accruals (ABSAC), lower ratio of market to book value of equity (MB), and larger firm size (LogTA).

Although BDO clients have the lowest mean of Total Accrual (TotAcc) - from Table 4 Panel C, apparently in terms of the mean of absolute value of total accruals - BDO clients are the largest, and CR clients are the lowest. As a consequence it is not surprising to find that BDO clients have the lowest mean of ratio of cash flow from operation to total assets (CFLOW), while CR clients have the largest CFLOW. BDO clients have the highest frequency of loss, and earnings are more volatile among BDO clients than other second-tier clients. $\mathrm{CR}$ clients have the largest mean of ratio of debt to total assets, followed by BDO clients. 


\section{RESULTS}

\section{Earnings Response Coefficient}

Table 5 includes the results of the ERC analysis. We run the test for the pooled regression and cluster-year regressions. The cluster-year regressions are based on pre-SOX, post-SOX, post-404, and post-Dodd Frank. Our variables of interest in the era after SOX (after 2002) are all insignificant, except for the 2005-2007 period where the coefficient for ERC of Crowe $\left(\mathrm{E}^{*} \mathrm{CR}\right)$ is negative and significant, which indicates that $\mathrm{CR}$ clients have lower ERC than GT clients. However, since this finding is for only one out of several years, we cannot conclude with confidence that Crowe clients have lower ERC. Thus, after controlling for other determinants of ERCs, there is no statistical difference between the ERCs of each of the individual second-tier clients and clients of other second-tier auditors for any of the specifications. The earnings quality of each of the second-tier clients is comparable to that of other second-tier clients. Therefore, to the extent that audit quality impacts earnings quality, our results suggest that each of the second-tier firm's audit quality is also comparable to that of other second-tier auditors in the past decade, 2000 to 2010. Thus, the results do not support hypothesis $\mathrm{H} 1$.

Using the pre-SOX sample, have a significant and negative coefficients for $\mathrm{E}^{*} \mathrm{BDO}$ and $\mathrm{E}^{*} \mathrm{CR}$ indicating that pre- SOX, $\mathrm{BDO}$ and $\mathrm{CR}$ clients have lower ERCs than GT clients. The time period is before the second tier differentiated themselves from the small firms in an effort to compete for large audit clients with the reduction of the large auditors such as Arthur Andersen.

We included F-tests to do the comparisons among BDO, MC and CR clients $^{2}$. In the ERC analysis, we find that the p-values of the F-tests are insignificant at 5 percent level signifying that there are no differences in the ERCs of BDO, MC and CR clients. However, we find two marginally significant differences in ERCs using the pooled sample for BDO vs. CR clients and MC vs. CR clients. The results show that $\mathrm{CR}$ clients have 
higher ERCs compare to $\mathrm{BDO}$ and $\mathrm{MC}$ clients. The results suggest that the higher ERC for CR clients in the pooled sample could be driven by the sample from 2002-2004 which has a large positive although insignificant ERC (3.579).

The coefficient on earnings ( $\mathrm{E}$ ) is positive and significant ( $\mathrm{p}$ value is less than 0.05) in the pooled sample. That is, earnings are value-relevant. For the pooled sample, the coefficients for earnings level (E) interactions with the control variables LOSS and earnings persistence (PERSIST) are negative and positively, respectively ( $p$ values is less than 0.05 ), consistent with prediction. The coefficient for the interaction of earnings level and tenure is positive and insignificant. The coefficients for the interaction between $\mathrm{E}$ and LnTA and the interaction between E and BETA are significant, and negative and positive, respectively, contrary to expectation. High correlation between the independent variables might be the cause.

\section{Abnormal Accruals}

Parameter estimates for Equation (2): Performance controlled Dechow et al. (2003) accrual model, are provided in Table 6 . The mean of the coefficient for property, plant, and equipment (PPE) is negative, as expected. With the inclusion of ROA in the model, the mean of the coefficient for unexpected change in accounts receivable, lag value of total accrual (LagTotAcc), and sales growth (Gr_Sales) are not as expected. Removing ROA from the model gives the expected results; thus, high correlation is the problem.

In Table 7, we compare the mean and median of absolute values of discretionary accruals between each second-tier auditor clients and the remaining second-tier auditor clients. Table 7 Panel A through D show that there is not enough evidence to conclude that any one of the secondtier clients is any different from the rest of the second-tier clients in terms of absolute value of discretionary accruals. 
Table 8 shows the results for the multivariate comparisons of the absolute values of abnormal accruals. We arbitrarily choose GT clients as the base in the regression, which means that we compare BDO, MC, and CR clients to GT clients. In the pooled regressions we do not find any evidence that $\mathrm{BDO}, \mathrm{MC}$, and $\mathrm{CR}$ clients are any different from GT clients in terms of absolute value of discretionary accruals. We also partition our sample by cluster-years related to major events that may have impacted the results, such as SOX, Section 404, and Dodd-Frank. We find that the results from the cluster-year regressions are generally consistent with the pooled regression.

Since the coefficients of BDO, MC, and CR clients only compare the abnormal accruals of their clients and GT clients, we also run F-tests to see whether abnormal accruals differ among BDO, MC, and CR clients. In all of the tests, we do not find any significant difference in abnormal accruals among $\mathrm{BDO}, \mathrm{MC}$, and $\mathrm{CR}$ clients.

As expected, in the pooled regressions, firms with larger total accruals (ABSAC) and larger market-to-book value $(\mathrm{MB})$ are more likely to have higher discretionary accruals. Firms with larger cash flow (CFLOW) have lower discretionary accruals. Moreover, firms with net loss (LOSS) are more likely to have lower discretionary accruals. The rest of the control variables are not significant.

\section{Summary AND Conchusion}

Policy makers and regulators are interested in increasing auditor choice. One way to accomplish this is to encourage Audit Committees to more frequently engage second-tier auditors, BDO, Grant Thornton, Crowe, and McGladrey. In a GAO (2008) study, regulators note that market share for the second-tier auditor is steadily increasing. Various second-tier audit quality studies also find a consistent trend of improved audit quality post-SOX and even no difference from Big 4 audit quality post-SOX. However, we note that these studies are not consistent in 
using all four firms in their sample and, therefore, in their final results. We examine audit quality of each of the second-tier auditors to determine if auditor choice is being increased while maintaining audit quality. We use two common measures of audit quality, earnings response coefficient and abnormal accrual, during the 2000 to 2010 period. We find no statistical difference in audit quality among the second-tier auditors especially in the period after Sarbanes- Oxley Act. The results are in support of policy makers and regulators, who are interested in increasing auditor choice, by encouraging Audit Committees to engage second-tier auditors.

\section{REFERENCES}

Ali, A. (1994). The incremental information content of earnings, working capital from operations, and cash flows. Journal of Accounting Research, 32, 61-74. http://dx.doi.org/10.2307/2491387

Ali, A., \& Zarowin, P. (1992). The role of earnings levels in annual earnings-returns studies. Fournal of Accounting Research, 30, 286-296. http://dx.doi.org/10.2307/2491128

Atiase, R. (1985). Pre-disclosure information, firm capitalization, and security price behavior around earnings announcements. Journal of Accounting Research, 23, 21-36. http://dx.doi.org/10.2307/2490905

Becker, L., DeFond, M., Jiambalvo, J. \& Subramanyam, K. (1998). The effect of audit quality on earnings management. Contemporary Accounting Research, 15, 1-24. http://dx.doi.org/10.1111/j.1911-3846.1998.tb0054 7.x

Boone, J.P., Khurana, I.K., \& Raman, K.K. (2010). Do the Big 4 and the Second-tier firms provide audits of similar quality? fournal of Accounting and Public Policy, 29, 330-352. http://dx.doi.org/10.1016/ j.jaccpubpol.2010.06.007

Cassell, C.A., Giroux, G., Myers, L.A., \& Omer, T.C. (2011). The emergence of Second-tier auditors: Evidence from investor perceptions 
of financial reporting credibility. Working paper. University of Arkansas.

Chaney, P., \& Jeter, D. (1992). The effect of size on the magnitude of longwindow earnings response coefficients. Contemporary Accounting Research, 8, 540-560. http://dx.doi.org/10.1111/j.1911-3846.1992.tb00 860.x

Chang, H., Cheng, C.S.A., \& Reichelt, K.J. (2010). Market reaction to auditor switching from Big 4 to Third-tier small accounting firms. Auditing: A fournal of Practice and Theory, 29, 83-114.

http://dx.doi.org/10.2308/aud.2010.29.2.83

Church, B.K., \& Shefchik, L.B. (2012). PCAOB Inspections and large accounting firms. Accounting Horizons, 26, 43-63. http://dx.doi.org/ 10.2308/acch-50077

Collins, D., \& Kothari, S. (1989). An analysis of inter-temporal and crosssectional determinants of earnings response coefficients. Fournal of Accounting and Economics, 11, 143-181. http://dx.doi.org/10.1016/01 65-4101(89)90004-9

Cox, C. (2005). Speech by SEC Chairman: Remarks before the 2005 AICPA National Conference on Current SEC and PCAOB Developments. U.S. Securities and Exchange Commission. Retrieved from http://www.sec. gov/news/speech/spch120505cc.htm.

Cullinan, C.P., Du, H., \& Zheng, X. (2012). Barriers to entry to the big firm audit market: Evidence from market reaction to switches to second Tier audit firms in the post-sox period. Research in Accounting Regulation, 24, 6-14. http://dx.doi.org/10.1016/j.racreg.2011.12.002

Dechow, P., Richardson, S., \& Tuna, I. (2003). Why are earnings kinky? An examination of the earnings management explanation. Review of Accounting Studies, 8, 355-384. http://dx.doi.org/10.1023/A:10244 81916719

Dey, R.M. (2010). The effect of client industry structure on client preference for privacy and auditor concentration. Managerial Auditing fournal, 25, 361-376. 
Dey, R.M. \& Robin, A. (2011). Second-tier auditing firms: Developments and prospects. The CPA fournal, June, 32-39. http://dx.doi.org/10.1 108/02686901011034171

Easton, P., \& Harris, T. (1991). Earnings as an explanatory variable for returns. Fournal of Accounting Research, 29, 19-36. http://dx.doi.org/ $10.2307 / 2491026$

Francis, J.R., Maydew, E.L., \& Sparks, H.C. (1999). The role of Big 6 auditors in the credible reporting of accruals. Auditing: A fournal of Practice and Theory, 18, 17-34. http://dx.doi.org/10.2308/aud.1999.18.2.17

Frankel, R.M., Johnson, M.F, \& Nelson, K.K. (2002). The relation between auditors' fee for nonaudit services and earnings management. The Accounting Review, 77, 71-105. http://dx.doi.org/10.2308/accr.2002.7 7.s-1.71

Freeman, R. (1987). The association between accounting earnings and security returns for large and small firms. Journal of Accounting and Economics, 9, 195-228. http://dx.doi.org/10.1016/0165-4101(87)9 0005-X

Government Accountability Office. (2003). GAO-03-864: Public Accounting Firms - Mandated Study on Consolidation and Competition. Retrieved from www.gao.gov/cgi-bin/getrpt?GAO-03-864.

Government Accountability Office. (2008). GAO-08-163: Audits of public companies - Continued concentration in audit market for large public companies does not call for immediate action. Retrieved from http:// www.gao.gov/new.items/d08163.pdf.

Gray, G.L., \& Ratzinger, N.V.S. (2010). Perceptions regarding the Big 4 accounting firms by financial statement preparers, users, and auditors. International Journal of Disclosure \& Governance, 4, 344-363. http:// dx.doi.org/10.1057/jdg.2010.15

Ghosh, A., \& Moon, D. (2005). Auditor tenure and perceptions of audit quality. The Accounting Review, 80, 585-612. http://dx.doi.org/10.23 08/accr.2005.80.2.585

Hayn, C. (1995). The information content of losses. fournal of Accounting and Economics, 20, 125-153. http://dx.doi.org/10.1016/0165-4101(95)0 $0397-2$ 


\section{The BRC Academy Journal of Business Vol. 4, No. 1}

Jenkins, D.S. \& Velury, U. (2011). The emergence of second-tier auditors in the post-SOX era: An analysis of accounting conservatism. Research in Accounting Regulation, 23, 172-176. http://dx.doi.org/10.1016/j.racreg. 2011.06.006

Kothari, S., Leone, W., \& Wasley, C. (2005). Performance matched discretionary accrual measures. Fournal of Accounting and Economics, 39, 163-197. http://dx.doi.org/10.1016/j.jacceco.2004.11.002

Kumar, K., \& Lim, L. (2013). Was Andersen less than its peers? A comparative analysis of audit quality. Working paper. George Washington University.

Kwon, S. (1996). The impact of competition within the client's industry on the auditor selection decision. Auditing: A Journal of Practice \& Theory, 15, 53-70.

Lai, K., \& Gul, F. (2008). Was audit quality of Laventhol and Horwath poor? Journal of Accounting and Public Policy, 27, 217-237. http://dx. doi.org/10.1016/j.jaccpubpol.2008.02.002

Lavieri, T. (2005). Bring back the Big Eight. Forbes.com, August 4, 2005.

O'Sullivan, K. (2007). Back to the Big Eight? CFO Magazine, September 1, 2007.

Pfeiffer, R., \& Elgers, P. (1999). Controlling for lagged stock price responses in pricing regressions: An application to the pricing of cash flows and accruals. Journal of Accounting Research, 37, 239-247. http://dx. doi.org/10.2307/2491406

Rajgopal, S., \& Venkatachalam, M. (2011). Financial reporting quality and idiosyncratic return volatility. Fournal of Accounting and Economics, 51, 1-20. http://dx.doi.org/10.1016/j.jacceco.2010.06.001

Teoh, S.H., \& Wong, T.J. (1993). Perceived auditor quality and the earnings response coefficient. Accounting Review, 68, 346-366.

\section{Web Appendix}

The web appendix for this paper is available at:

http://dx.doi.org/10.15239/j.brcacadjb.2014.04.01.wa01 


\section{Citation Information}

Dey, Mithu R. and Lucy S. Lim. "Audit Quality of Second-Tier Auditors: Are All Created Equally?” The BRC Academy fournal of Business 4, no. 1 (2014): 1-26. http://dx.doi.org/10.15239/j.brcacadjb.2014.04.01.ja01 
26 The BRC Academy Journal of Business Vol. 4, No. 1

\section{Notes}

1. Earnings surprises are proxied using earnings level (E) and lag earnings level (LagE) following Pfeiffer and Elgers (1999). Earnings surprises $=\mathrm{a} \triangle \mathrm{E}+\mathrm{bE}$. So, the coefficient of interest is $\mathrm{a}+\mathrm{b}$. However, we can rearrange the equation into $\mathrm{aE}-\mathrm{aLagE}+\mathrm{bE}=(\mathrm{a}+\mathrm{b}) \mathrm{E}-\mathrm{aLagE}$ and just use the coefficient estimate for $\mathrm{E}$ to measure ERC.

2. We thank an anonymous referee for suggesting this idea. 